\title{
TERMS RELATED TO PRACTICE RULES AND REGULATIONS OF ORGANIC BEEKEEPING PRODUCTION IN TURKEY
}

Lale TAŞ

\author{
GAP Agricultural Research Institute, Şanlıurfa
}

ORCID ID:0000-0001-7113-0353

\section{ÖZET}

Organik tarım üretimi; yönetmeliğin izin verdiği çevreye ve insan sağlığına zarar vermeyen kimyasal ilaçların kullanıldığı, insan sağlığına ve doğaya dost bir üretim olup üretim miktarından ziyade ürünün kalitesine öncelik veren ve her aşaması kontrol ve sertifikasyon şirketleri tarafından kontrol edilip sertifikalandırılan bir üretimdir şeklidir.

Organik Arıcılık ise, üretimden tüketime kadar her evresinde arılara kimyasal ilaçlama ve suni beslenme uygulanmadan, doğası bozulmamış florada veya organik tarım alanlarında yapılan ve kontrol sertifikasyon şirketleri tarafından kontrol edilip sertifikalandırılan bir üretimdir.

Arıcılık; hem Avrupa ülkelerinde hem de ülkemizde özellikle kırsal alanda gelir düzeyi düşük üreticilerin ve daha çok toprak sahibi olmayan üreticiler için önemli bir gelir kaynağıdır. $\mathrm{Bu}$ yönüyle kırsal kesimde mikro düzeyde, ülke ekonomisine ise makro düzeyde katma değer kazandırmaktadır.

Arıdan elde edilen ürünler üretimden market raflarında yerini alıncaya kadar gıda güvenliğini olumsuz etkileyen risk faktörlerinin tehdidi ile karşılaşmaktadırlar. Bu nedenle organik arıcılıkta amaç kaliteyi artırmak olduğu için organik arıcılığın önemi artmaktadır.

Tarım Ve Orman Bakanlığı, Organik Tarım Bilgi Sistemine (OTBİS) göre 2019 yılında, Türkiye'de organik arıcılık yapan 249 işletme organik arıcılık yapmakta toplam organik kovan sayıs1 50.100, toplam organik bal üretim miktarı ise 576.76 tondur. Aynı zamanda Tarım Ve Orman Bakanlığı, Organik Tarım Bilgi Sistemine göre 2019 yılında, Türkiye'de geçiş sürecinde arıcılık yapan 159 işletme mevcut, geçiş sürecinde toplam 21.484 kovan bulunmaktadır

Ülkemizin bu potansiyelini artırmak ve sürdürülebilirliğini sağlamak için, organik arıcılık ürünlerinin güvenilir ve daha kaliteli üretilmesiyle gerçekleştirilebilir. Bunun içinde Organik arıcılık ürünleri üretimi ve tüketimi yaygınlaştırılmalıdır.

Anahtar kelimeler: Organik Tarım, Organik Arıcılık, Bal, Mevzuat

\author{
ABSTRACT \\ Organic farming production; To the extent permitted by the regulation, it is a production in \\ which chemical drugs are used that are friendly to human health and nature, and do not harm


the environment and human health; It is a form of production that gives priority to the quality of the product rather than the amount of manufacture, and every stage is checked and certified by control and certification.

Organic Beekeeping, on the other hand, does not apply chemical drugs and artificial nutrition to bees at every stage from production to consumption, It is a production that is carried out on intact natural flora or organic farming areas and is controlled and certified by control certification companies.

Beekeeping; producers with low income, especially in rural areas, both in European countries and in our country and it is an important source of income for producers who do not have land. With this aspect, it adds added value at the micro-level in the rural areas and at the macro level in the country's economy.

The products obtained from bees are faced with the threat of risk factors that negatively affect food safety during the process of taking their place on the market shelves from production. For this reason, the importance of organic beekeeping increases as the aim is to increase the quality of organic beekeeping.

According to the Organic Agriculture Information System (OTBİS) of the Ministry of Agriculture and Forestry, in 2019, There are 249 enterprises engaged in organic beekeeping in Turkey. Organic beekeeping, the total number of organic hives is 50.100 and the total organic honey production is 576.76 tons.

Moreover according to the Organic Agriculture Information System of the Ministry of Agriculture and Forestry, in 2019, 159 enterprises engaged in beekeeping in the transition process in Turkey present, it has a total of 21484 hives in transition.

To increase this potential of our country and to ensure its sustainability, It can be achieved by producing reliable and better quality organic beekeeping products. For this, the production and consumption of organic beekeeping products should be expanded.

Keywords: Organic Agriculture, Organic Beekeeping, Honey, Rugulation

\section{INTRODUCTION}

Bulut, (2011) Due to the use of chemical pesticides and pesticides in both agricultural production and animal production As human and animal health is under threat, it also harms the environment, so the interest in organic agriculture is increasing. Practices to increase productivity and income in production threatened life and caused the disruption of the natural balance.

Yürüdür, (2010) Since conventional production in agricultural and animal production harms human health and the environment, scientists have turned to organic agriculture as well as 
sustainability as an alternative to conventional production. Although Organic Agriculture emerged at the beginning of the 20th century, it has been increasingly spread in developed countries after 1970. In Turkey, organic farming has increased over time until today to meet demand from European companies, starting in 1980.

However, although our country has a great potential in terms of organic production, despite its rich vegetation and natural flora, its share in the total organic production in the world is low.

Azizoğlu, (2012) Purpose in organic production; In the fight against disease-causing pests, it is not to eliminate the pest completely, but to minimize its damage.

Lodesani, (2003) Organic livestock, It is a controlled and certified form of animal production with organic production techniques for consumers who prefer products that do not put human health at risk.

Akyol, (2009) Organic beekeeping; Every stage from production to consumption is recorded and controlled without the use of chemical drugs, artificial nutrition and It is a production method certified by control and certification companies, friendly to human and environment, and preserving natural balance.

Demiryürek, (2016) The transition period in organic beekeeping production is one year. Organic honey can be defined as honey that is produced from nature stracture intact and does not contain residues.

Çukur, (2016) One of the most important income sources of family members in rural areas is beekeeping. Products obtained in beekeeping; honey, propolis, pollen, beeswax and similar products. These beekeeping products provide added value to producer income in rural areas.

Human health is at risk due to chemical pesticides used in beekeeping and residue in bee products. Since these residues endanger human health and to increase the quality of bee products, the importance of organic beekeeping has increased. Reducing starve and nutritional problems caused by the increasing population is possible not only by increasing food production but also by producing quality and qualified food products (TUBİTAK, 2003).

Çukur, (2016) First of all, due to reasons such as the residue problem and human health that we sometimes encounter in honey, export has also been a problem. This problem also negatively affected the economy. Therefore, it has been inevitable to implement and separate organic beekeeping.

Doğaroğlu, (2012) In beekeeping production, Chemical pesticides, heavy metals, genetically modified organisms (GMOs) and similar factors are environmental factors. The factors originating from the farmer; They are antibiotics and chemical drugs used to protect the bee from diseases and pests and they are imitation and adulteration of honey, beeswax and sugar products made to protect the comb. 


\section{RESEARCH FINDINGS \\ ORGANIC BEEKEEPING IN TURKEY}

Ministry of Agriculture and Forestry, the Organic Farming Information System (OTBİS) between the years 2015-2019 by organic beekeeping in Turkey Production Data (Figure 1) is given.

In 2015, the number of farmers engaged in organic beekeeping production was 322, the number of hives was 38,296, and the production amount was 674.54 tons. In 2016, the number of farmers engaged in organic beekeeping production was 276, the number of hives was 40,371 and the production amount was 349 tons. In 2017, the number of farmers engaged in organic beekeeping production was 318 , the number of hives 48,153 , and the production amount was 393.2 tons. In 2018, the number of farmers engaged in organic beekeeping production was 334, the number of hives was 51,742, and the production amount was 494.9 tons. In 2019, the number of farmers engaged in organic beekeeping production is 249, the number of hives is 50,100, and the production amount is 576.76 tons. The number of producers, which was 322 in 2015, decreased to 249 in 2019. While the number of organic hives was 38,296 in 2015, the number of organic hives increased to 50,742 in 2019. In 2016, the organic beekeeping production amount decreased by 14\% compared to 2015. However, after 2016, an increase was observed in the production amount every year.

While the organic beekeeping production amount was 674.54 tons in 2015, it decreased to 576.76 from 2019. While the number of organic hives was 38,296 in 2015, the number of organic hives increased by 50,100 in 2019. In 2019, the number of organic hives increased by 30\% compared to 2015.

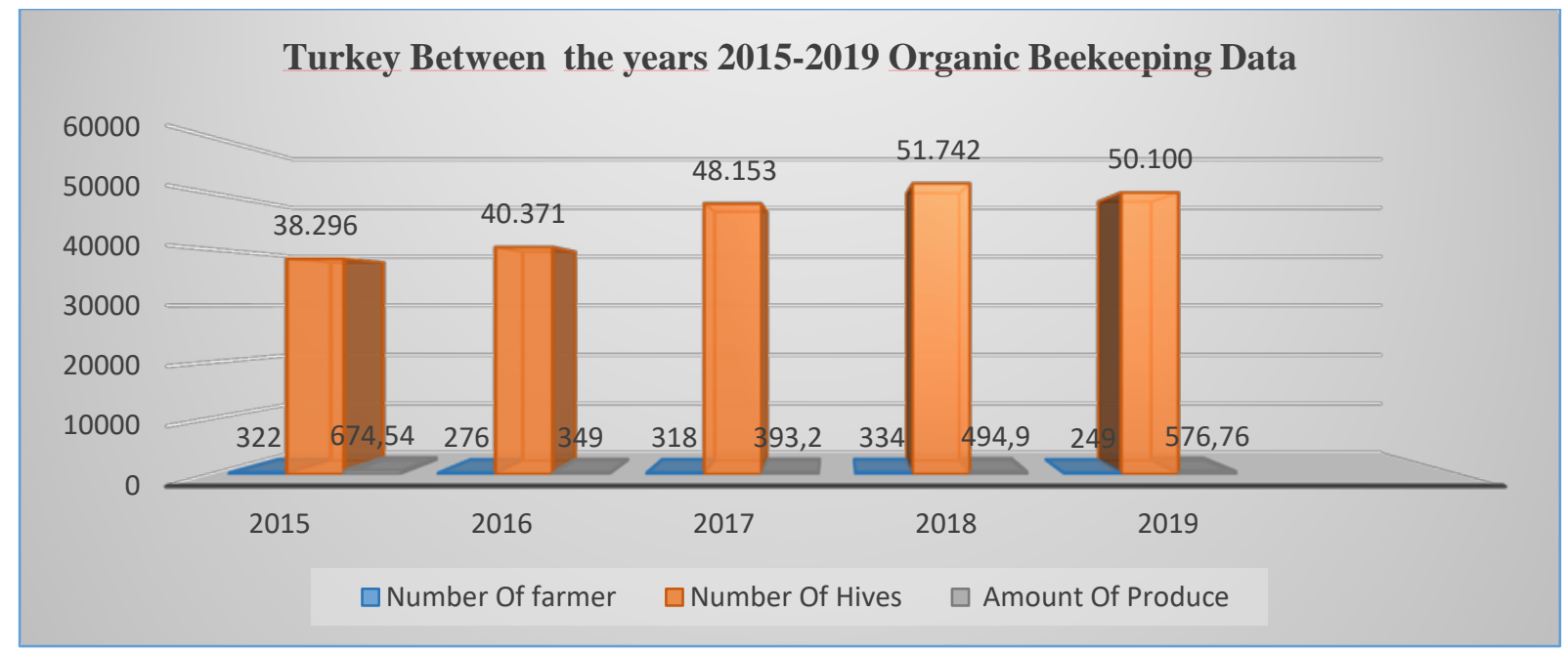

Fıgure1 : Turkey between the years 2015-2019 Organic Beekeeping Data

Received 23 December 202D; Received in revised form 25 December 2020; Accepted 25 November 2020;

Available unline 27 December 2020

dai: 10.46291//[CDNTECHval4iss33pp65-76 
Source: Ministry of Agriculture and Forestry Organic Agriculture Information System (OTBİS) 2020

Ministry of Agriculture and Forestry, the Organic Farming Information System (OTBİS) based in Turkey between 2015-2019 Transition Year Beekeeping Production Data (Figure 2) are given. While the number of producers in the transition period was 238 in 2015, the number of producers decreased to 159 in 2019. While the number of hives in the transition period was 32,680 in 2015, the number of hives in the transition period decreased to 21,484 in 2019.

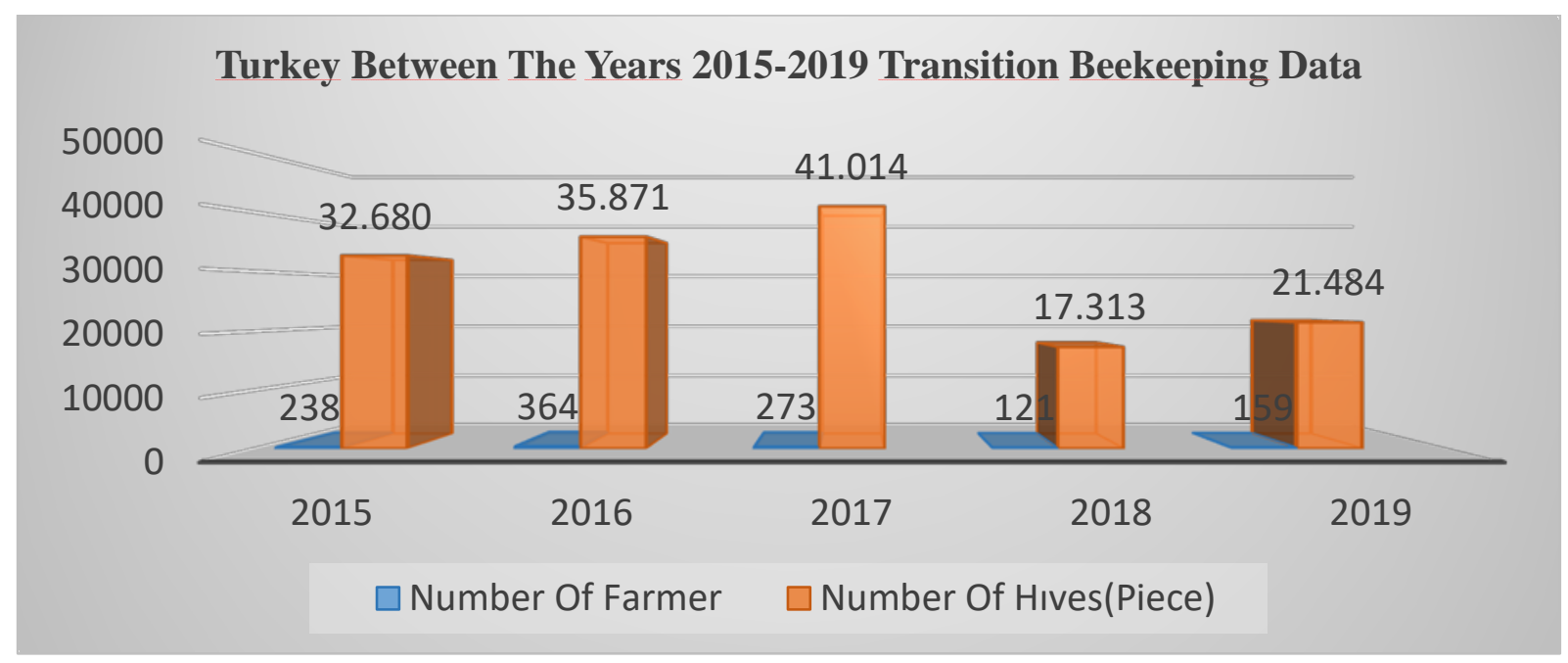

Figure2: Turkey between the years 2015-2019 Transition Beekeeping Data

Source: Ministry of Agriculture and Forestry Organic Agriculture Information System (OTBİS) 2020

Ministry of Agriculture and Forestry, the Organic Farming Information System (OTBİS) based in Turkey between 2015-2019 Year in 2019 for organic beekeeping production in the first three provinces (Figure 3) are given.

According to the amount of organic beekeeping production in 2019, in Turkey; Van is in the first place with 167,921 tons of production, Mersin is in the second place with 89,1 tons of production and Elazığ is in the third with 38,05 tons. 


\section{Orgamic Beekeeping Amount Of Production in 2019 (Tone) Top Three Proviences}

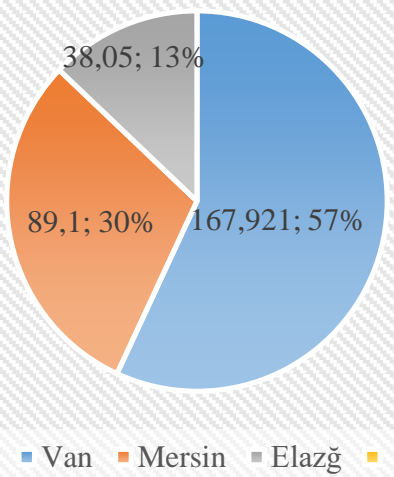

Figure 3: Organic Beekeeping Amount of production in 2019 (Ton) Top Three Provinces

Source: Ministry of Agriculture and Forestry Organic Agriculture Information System (OTBİS) 2020

According to the Organic Agriculture Information System of the Ministry of Agriculture and Forestry (OTBİS), organic beekeeping product types between 2015-2019;

In Turkey, in 2015 while organic beekeeping honey crop varieties honey, pollen, propolis, royal jelly, beeswax, in 2016 organic beekeeping product is only organic honey.

In 2017 while Organic bee product types honey, pollen, royal jelly, propolis, the products in 2018 are honey and pollen. In 2019, only organic honey was produced as a product type.

\section{LEGISLATION IN ORGANIC LIVESTOCK}

Bülbül, (1998) With organic agriculture that started in our country in 1984, organic products have been checked and certified by foreign companies. These foreign companies have created the Organic Agriculture Regulation based on the IFOAM regulation in force in Europe and different countries. European Union countries and other countries issued a regulation numbered EEC 2092/91 on 24.06.1991 to make a common arrangement in organic agriculture product trade. The same regulation has been applied in our country as of 24.06.1991.

Kismalı, (1998) and Öztürk, (2004) the first organization established in 1992 to promote organic agriculture in Turkey ETO (Ecological Agriculture Organization) is association.

Emir, (2014) On 03.12.2004, a legal infrastructure was established for the Organic Agriculture Law No. 5262.

Önald1, (2014) Organic production in our country by the organic agriculture legislation of importer countries; It has been prepared on the basis of the European Union council regulation numbered 2092/91 in plant production after 1991 and in animal production after 1999. The European Union by modifying the aforementioned regulations in the following years, the EC 834/2007 council regulation in 2007, the commission regulation containing Received 23 December 2020; Received in revised farm 25 December 2020; Accepted 25 November 2020; 
889/2008 implementation rules in 2008, and then the 505/2012 commission implementation regulation was prepared by updating the regulation on nutrition in organic livestock. The Regulation on the Principles and Implementation of Organic Agriculture dated 18.08.2010 and numbered 27676 was published in the Official Gazette. This regulation was prepared based on the Organic Agriculture Law numbered 5262 and dated 01.12.2004 and entered into force as of 01.01 .2009 and is in compliance with the EU's regulation 834/2007. The regulation on the principles and practices of organic agriculture dated 06.10.2011 and numbered 28076 was published in the Official Gazette (Karaaslan, 2012). The purpose of the regulation; Organizing organic farming activities, planning organic farming production, regulating the marketing of organic farming products, promoting organic agriculture and spreading organic agriculture (Karaaslan, 2012). In the same regulation 14.08.2012 (Official Gazette No.28384), 24.05.2013 (Official Gazette No.28656), 15.02.2014 (Official Gazette No.28914), 22.07. Necessary arrangements were made according to the conditions of the day in 2015 (Official Gazette No. 29422) and 10.01.2018 (Official Gazette No. 30297) (Boz \& Kaynakç1, 2018).

\section{RULES TO BE FOLLOWED IN ORGANIC BEEKEEPING CONTRACT BY THE REGULATION ON ORGANIC AGRICULTURAL PRINCIPLES AND APPLICATION:}

According to the Regulation on Principles and Application of Organic Agriculture issued by the Ministry of Agriculture and Forestry, the written regulation about "Organic Bee Breeding" prepared in Section 3, Article 23 must be complied with. Rules to be followed in Organic Bee Farming (Anonymous a) ;

\section{Anımal Breedıng;}

The beekeeping where the beekeeping will be carried out the area should be checked by an authorized expert approved by the control and/or certification company.

Choice of race; their resistance to diseases is taken into consideration. Breeds and local ecotypes of Apis mellifera species are common in general.

Capacity increase; colonies are separated or swarms / hives from other businesses where organic beekeeping is carried out.

According to the regulation, bee swarms obtained from businesses engaged in normal beekeeping are applied to a one-year transition period.

With the approval of the authorized institution, the normal bee colonies existing in the enterprise can be used for transition to organic beekeeping.

The beeswax obtained in the transition process in beekeeping can be changed with the beeswax obtained in organic beekeeping.

Bees in their hives for the winter should contain enough honey and pollen for that period.

Received 23 December 2020; Received in revised farm 25 December 2020; Accepted 25 November 2020;

Available online 27 December 2020

doi: 10.46291/ICONTECHvo|4iss3pp65-76 
The transition period for products to be considered organic in organic beekeeping is one year.

When medicinal drugs are used in bees, the type of product used, diagnosis, dosage, dosage form, duration of treatment, the active pharmacological substance should be recorded.

Before the products are put on the market as organic products, the authorized institution is informed.

Feeding is allowed only if the colonies are at risk due to climatic conditions.

In organic bee nutrition are used Organic honey, organic sugar syrup and organic sugar.

Feeding should be recorded. In this record used are written the type of the product, the amount and date given, the data of the hives.

\section{Care İn Organic Beekeeping;}

Both the hive information and the area where the bees are kept are recorded.

The bees inside the combs cannot be killed during the harvest. İt is not permit that brood honeycombs to use so that honey filter.

When it comes to queen change, the old queen is not killed and the wings of the queen bee cannot be cut.

If there is a male bee eye with Varroa disease, it is only allowed to be destroyed in this case.

It is forbidden to use chemical synthetics to repel flies in honey harvest.

All measures taken from the production of beekeeping products to their harvest (production, harvest, processing, storage) are recorded.

\section{Settlement İn Organic Beekeeping;}

Bees should have access to water and there should be sufficient sources of pollen, natural nectar and nectar.

Within a $3 \mathrm{~km}$ radius in the beekeeping area, nectar and pollen sources should be from organically produced products, not from conventionally produced products.

Hives in organic beekeeping should be placed in a location away from non-agricultural production centres (highways, city center, industry, etc.).The necessary conditions for the realization of these measures must be provided by the enterprice.

If the sweat of the hives is changed, the control and certification company should be informed.

\section{Properties Of Materials And Hives To Be Used İn Beekeeping;}

The hives should be made of environmentally friendly natural materials that do not harm the products obtained from the bee. 
Beehives cannot be painted with paints containing chemicals. In other words, beehives should be covered with natural products such as propolis, herbal oils and beeswax.

Beeswax should be preferred for the new frame.

If organic beeswax cannot be found in the market during the transition period, the control and certification company may permit the use of conventional beeswax according to analysis.

If there are juveniles in the chambers above the frames, honey milking is not suitable.

To protect the honeycomb, hive and frame against pests, Rodenticides can only be applied in traps or products permitted in Annex-2 of the current regulation can be applied.

During the relocation of the hives, bees should not be exposed to stress.

Organic beekeeping is prohibited in areas where air (by plane) spraying is applied.

\section{The Rules To Be Followed For The Prevention Of Diseases İn Organic Beekeeping;}

Breeds resistant to diseases and pests should be selected.

Queen bee should frequently be renewed .

Hives should constantly be checked .

Male bee eyes should be checked.

Materials should be cleaned frequently and contaminated materials removed.

Beeswax should be refreshed frequently.

In order for bees to gain resistance against diseases and infections, the needed pollen and honey should be keep in the hives.

If the colonies become infected despite the implementation of the precautions, the colonies should be treated and isolated in separate hives if needed.

\section{Veterinary Medicinal Products Should Comply With The Following Principles;}

It must be licensed by the Ministry of Agriculture and Forestry.

Phytotherapy or homoeopathic treatment should be used instead of chemical drugs, provided that it is suitable for treatment.

If phytotherapeutic and homoeopathic treatments do not cure the disease, chemical-containing medication is used under the responsibility of the control and certification company. However, it is forbidden to use chemical-containing drugs to protect the bee.

Fighting Varroa; Formic acid, lactic acid, acetic acid, oxalic acid and menthol, thymol, eucalyptol or camphor are applied for bees. As a result of their use, there is no transition period for bees. 
If allopathic products are used for the treatment of the disease, the colonies have used for treatment at that time are placed in the isolated hives.In addition, beeswax should be replaced with beeswax obtained in organic beekeeping. A one-year transition period applies for these colonies.

\section{DISCUSSION AND CONCLUSION}

The residue problem in honey due to the use of pesticides is very important.

Pesticides have disadvantages such as damaging the biological balance, causing environmental pollution and harming human health by making residues.

The EU, which ranks second in honey production in the world, is also the world's largest honey importer, as it cannot meet its internal consumption.Although the production of the honey exporter in Turkey competitiveness in this area is at a disadvantage (Sarıçoban, 2016; TEPGE, 2019).

In order to increase honey quality in our country, the most important problems of beekeeping should be resolved. The main problem is the technical issues faced by the manufacturers. Honey quality is based on the properties of all materials used, from honey production to honey harvest. Therefore, beekeepers should be equipped with the necessary technical information and make a very good choice (Saner ve ark., 2011).

We are below the world average in terms of hive yield, so it is imperative to increase the hive yield as well as honey quality. Queen bee and male bee production should be given enough attention (Seven ve Akkılıç, 2005; Ünye Ticaret Borsası, 2014).

As the green area and vegetation of the country increases, the efficiency, quality and sustainability of honey production increases. Therefore, people should be made aware of environmental awareness. It should be emphasized that unconscious and high-dose drugs cause serious losses in the beehives, especially during the flowering period.

We can say that organic beekeeping, which developed within the scope of organic agriculture activities, which was implemented in the 1980s to meet the request from the EU, has not become widespread enough.

Considering the existence of sufficient legislation on the subject, the number of registration and certification institutions, and the payment of organic production support payments, In addition to these measures to increase production, measures and incentives to increase consumption should be developed.

\section{REFERENCES}

1.Anonima,https://www.mevzuat.gov.tr/mevzuat?MevzuatNo=14217\&MevzuatTur=7\&Mevz uatTertip=5 ( Erişim Tarihi: 20.08.2020) 
2-Akyol, Mehmet T., 2009. Organik Arıcılık Makalesi (Standart Dergisi Y11:48 Sayı: 567 Ağustos 2009) (ISSN:1300 8366) Sayfa:85

3-Azizoğlu, U., ve ark. 2012 Erciyes Üniversitesi Fen Bilimleri Enstitüsü Dergisi, 28(5):375381

4-Bulut, S., ve ark. 2011 Organik Tarım Eğitim Kitabı, M Grup Matbaacılık A.Ş., Kayseri s.1 5-Bülbül, S., Bayturan, N., Ayan, R., 1998. Ekolojik tarım ve ilkeleri. Ekolojik (Organik, Biyolojik) Tarım,

6-Boz, İ., Kaynakçı, C. 2018. Possibilities of Improving Organic Farming in Turkey. International Journal of Innovation and Economic Development. 5(4):25-34.

7-Çukur, F., ve ark. (2016) AB ve Türkiye'de Arıcılık Faaliyetine Yönelik Gıda Güvenliği * Uygulamaları: Sorunlar ve Öneriler, Tarım Ekonomisi Dergisi 22-2 (2016), s 87-95

8-Demiryürek, K. (2011). Organik tarım kavramı ve organik tarımın dünya ve Türkiye'deki durumu. GOÜ, Ziraat Fakültesi Dergisi, 28(1), 27-36.

9-Demiryürek, K., 2016, Organik Tarım Ve Ekonomisi Kitabı, Giresun, s.48

10-Doğaroğlu, M.2012. Arı Ürünlerinde Üretim ve Tüketiminde G1da Güvenliği, Bal ve Diğer Arı Ürünleri ile Sağlıklı Yaşam Platformu, 5 Temmuz, İstanbul

11-Emir, M., ve Demiryürek, K., Adnan Menderes Üniversitesi Ziraat Fakültesi Dergisi 2014; $11(2): 21-28$

12-Karaaslan, V., 2012. Organik Tarım 2 . (Güncellenmiş ) Bask1 2012,Ankara. 39 s.

13--Kısmalı, İ., 1998. Ekolojik (Organik, Biyolojik) Tarım. Ekolojik Tarım Organizasyonu Derneği (ETO). İzmir.

14-Önaldı, A.T., 2014 Dünya Ve Türkiye' De Organik Büyükbaş Ve Küçükbaş Hayvan Yetiştiriciliğine Yönelik Yasal Düzenlemelerin Karşılaştırılması, Selçuk Üniversitesi, Zootekni Anabilim Dalı, Nisan-2014 KONYA, s.65

15-Saner, G., Yücel, B., Yercan, M., Karaturhan, B., Engindeniz, S., Çukur, F., \& Köseoğlu, M. (2011). Organik ve Konvansiyonel Bal Üretiminin Teknik ve Ekonomik Yönden Geliştirilmesi ve Alternatif Pazar Olanaklarının Saptanması Üzerine Bir Araştırma: İzmir İli Kemalpaşa İlçesi Örneği. Tarımsal Ekonomi ve Politika Geliştirme Enstitüsü, Ankara.

16- Sarıçoban, K. (2016) Ülkelerin ihracat rekabet güçlerinin belirlenmesi: Türkiye ve G-20 ülkelerinin karşılaştırmalı analizi. Süleyman Demirel Üniversitesi Sosyal Bilimler Enstitüsü İktisat Anabilim Dalı, Doktora Tezi, Isparta.

17-Sarıçoban, K. (2016) Ülkelerin ihracat rekabet güçlerinin belirlenmesi: Türkiye ve G-20 ülkelerinin karşılaştırmalı analizi. Süleyman Demirel Üniversitesi Sosyal Bilimler Enstitüsü İktisat Anabilim Dalı, Doktora Tezi, Isparta. 
18-Seven, İ., \& Akkılıç, M. (2005). Elazığg'daki arıcılık işletmelerinin üretim ve pazarlama problemlerinin tespiti ve çözüm önerileri. Lalahan Hayvancılık Araştırma Enstitüsü Dergisi, 45, 41-52.

19-TEPGE, (2019) Tarım Ürünleri Piyasaları, Arıcılık. Ankara.

20-Tubitak.,2003. Vizyon 2023, Bilim ve Teknoloji Öngörüsü Projesi, Tarım ve Gıda Paneli Son Rapor, Temmuz, Ankara, s.55.

21-Ünye Ticaret Borsası (2014) Arıcılık ve Bal Raporu

22-Yürüdür, E., ve ark. 2010 Elektronik Sosyal Bilimler Dergisi, Bahar-2010 C.9 S.32 (402424)

23-. http://www.teknikari.com/ ( Erişim Tarihi: 20.07.2020).

24-http://www.tuik.gov.tr/AltKategori.do?ust_id=11\&ust_adi=N\%FCfus (Erişim Tarihi: 20.07.2020).

25-.http://www.tuscert.com/organik-aricilik.html

26- https://www.tarimorman.gov.tr/Konular/Bitkisel-Uretim/Organik-Tarim?Ziyaretci=Ciftci

27- http://orser.com.tr/Sayfa.aspx?pid=28\&cid=0\&Lang=TR

28-http://www.tuscert.com/organik-aricilik.html 